DOI: 10.14720/aas.2016.107.2.06

Agrovoc descriptors: Cichorium intybus, chicory, Agrobacterium rhizogenes, root hairs, transformation, genetic processes, genetic transformation

Agris category code: F30

\title{
High-efficient transgenic hairy roots induction in chicory: re-dawn of a traditional herb
}

\author{
Sara KABIRNATAJ ${ }^{1}$, Ghorbanali NEMATZADEH ${ }^{1}$, Jafar ZOLALA $^{2}$, Ahmad Farhad TALEBI $^{3 *}$
}

Received Janury 15, 2016; accepted April 30, 2016.

Delo je prispelo 15. januarja 2016, sprejeto 30. aprila 2016.

\begin{abstract}
Plant roots can be manipulated by Agrobacterium rhizogenes to stimulate the production of heterologous proteins for pharmaceutical applications as green cell-factories. During the present study, four bacterial strains (A4, ATCC15834, ATCC11325 and A13) in combination with three cocultivation media (MS, B5, LS) were examined to establish an efficient and reliable transformation system for chicory (Cichorium intybus L.) using A. rhizogenes. The maximum chicory hairy roots induction was achieved using A13 strain. The observation confirmed that MS medium was more effective on hairy root growth. Dried biomass accumulation of hairy roots infected by A13 strain was $1.10 \mathrm{~g} \mathrm{l}^{-1}$ in MS medium which was significantly higher than those grown in LS and B5 medium (0.88 and $0.72 \mathrm{~g} \mathrm{l}^{-1}$, respectively). Betaglucuronidase (GUS) gene was introduced by A13 strain carrying the pCAMBIA1304 binary vector. The results showed that the highest frequency of transformation $(63.15 \%)$ was achieved using A13 strain and MS cultivation medium. Detection of GUS and hptII genes by PCR and GUS histochemical localization confirmed the integrative transformation in hairy roots. In conclusion, the whole process was successfully optimized as a pre-step to manipulate the chicory hairy root cells to improve the unique potential of secondary metabolite production.
\end{abstract}

Key words: Chicory, A. rhizogenes, hairy root, GUS, A13

\section{IZVLEČEK}

\section{UČINKOVITA INDUKCIJA TRANSGENIH LASASTIH KORENIN PRI NAVADNEM POTROŠNIKU: NOVA UPORABA TRADICIONALNEGA ZELIŠČA}

Korenine lahko $\mathrm{z}$ bakterijo Agrobacterium rhizogenes spremenimo v "zelene celične tovarne", ki proizvajajo heterologne proteine, uporabne $\mathrm{v}$ farmaciji. $\mathrm{V}$ tej raziskavi je bila preučevana uporaba štirih sevov bakterije A. rhizogenes (A4, ATCC15834, ATCC11325 in A13) v kombinaciji s tremi ko-kultivacijskimi gojišči (MS, B5, LS) za vzpostavitev učunkovitega transformacijskega sistema za navadni potrošnik (Cichorium intybus L.). Največja indukcija lasastih korenin je bila dosežena z uporabo seva A13. Opazovanja so potrdila, da je bilo za rast lasastih korenin učinkovitejše MS gojišče. Biomasa lasastih korenin, okuženih s sevom A13 je bila $1.10 \mathrm{~g}$ $1^{-1}$ na MS gojišču, kar je bilo značilno več kot pri rasti korenin na gojiščih LS in B5 $\left(0,88\right.$ in $\left.0,72 \mathrm{~g} \mathrm{l}^{-1}\right)$. Gen za betaglukuronidazo (GUS) je bil vnešen $\mathrm{z}$ A13 sevom, ki je vseboval pCAMBIA1304 binarni vektor. Izsledki so pokazali, da je bila največja frekvenca transformacije $(63,15 \%)$ dosežena z uporabo A13 seva in MS gojišča. Detekcija GUS in hptII genov s PCR in GUS histokemično lokalizacijo je potrdila njuno vključitev v lasaste korenine. Celoten proces je bil uspešno optimiziran kot predstopnja $\mathrm{v}$ obdelavi celic lasastih korenin navadnega potrošnika za izboljšanje sposobnosti tvorbe sekundarnih metabolitov.

Ključne besede: navadni potrošnik, A. rhizogenes, lasaste korenine, GUS, A13

\footnotetext{
1 Genetic and Agricultural Biotechnology Institute of Tabarestan (GABIT), Sari Agricultural Sciences and Natural Resources University, Iran

Department of Plant Biotechnology, Faculty of Agriculture, Shahid Bahonar University of Kerman, Iran

Department of Genetics, Faculty of Microbial Biotechnology, Semnan University, Iran; corresponding author: aftalebi@semnan.ac.ir
} 


\section{INTRODUCTION}

Induction of hairy roots in herbal plants by soilborne bacterium Agrobacterium rhizogenes provides a useful systems for synthesis of valuable pharmaceutical compounds, among them also secondary metabolites. The induced hairy roots exhibit several superior features such as rapid growth, genetic and biochemical stability, ability to growth in hormone-free media, ease of maintenance and the ability to synthesize a variety of chemical compounds (Giri and Narasu, 2000). A. rhizogenes can also co-transfer the T-DNA of binary vectors which allows production of transgenic plants possessing foreign genes after regeneration from hairy roots (Lee et al., 2004; Tomilov et al., 2007). Transformation of several plant species including carrot (Srinivasan et al., 2014), cauliflower (Puddephat et al., 2001), mustard (Kastell et al., 2013), and potato (Otani et al., 1993) upon A. rhizogenes-mediated cotransformation has been reported. Typically, the regenerated plants are genetically stable and often have morphological and physiological changes like wrinkled leaves, extremely abundant and plagiotropic root system and also reduced apical dominance, internode length and leaf size (Tepfer, 1984). Chicory (Cichorium intybus L.), a member of Asteraceae family is traditionally used to cure various ailments and has also other beneficial properties. It has the ability to prevent liver damages, anti-ulcerogenic (ulcer healing effects) and anti-inflammatory effects, appetizer, digestive, stomachic (improving stomach function and increasing appetite), liver tonic, cholago, cardiotonic (acts as a stimulant of the heart). The root, leaf and seeds of chicory contain a number of medicinally important compounds such as inulin, sesquiterpene lactones, coumarins, flavonoids and vitamins (Nandagopal and Kumari, 2007). Recent pharmacological investigation of the root extract of this plant revealed immunomodulation and anticancer properties (Karimi et al., 2014). Sesquiterpene lactones which have high anti- cancer property were isolated from A. rhizogenes LBA 9402 transformed hairy roots of $C$. intybus in 2002 (Malarz et al., 2002). Moreover, in an investigation done by Bais et al. (2000) the possible benefits of coumarins production in hairy root cultures of $C$. intybus was proven; 4.06 and 3.71 fold increase in esculin and esculetin production as derivative of coumarin were achieved in induced hairy roots using fungal elicitors.

Several attempts have also been made to enhance hairy root induction, and to regulate pathways leading to production of important bioactive compounds. It was previously confirmed that optimizing the composition of organic/inorganic nutrients of the media for hairy root cultures is essential to gain high production of secondary metabolites (Sivakumar, et al., 2005). Different concentrations of salts and elicitors in culture media have a major role in hairy root growth and induction of secondary metabolites production (Wang and $\mathrm{Wu}, 2013$ ). It is worth to mention that hairy roots growth drastically increase by change in some major mineral components (Pakdin et al., 2014).

In the present study the effect of different cocultivation media and various $A$. rhizogenes strains on the induction and growth of hairy root cultures of chicory were studied. Moreover, A. rhizogenes strain A13 (MAFF02-10266) (Daimon et al., 1990) harboring a wild mikimopine-type Ri plasmid and pCAMBIA1304 vector was used for GUS transformation in hairy root of cotyledon explants. Introduction of GUS reporter gene was demonstrated by histochemical staining with $\mathrm{X}$ glucuronide. The aim of the work presented here was improving a genetic transformation protocol for $C$. intybus and investigating the potential for genetic manipulation of the important secondary metabolite pathways.

\section{MATERIALS AND METHODS}

\subsection{Plant material}

Chicory's seeds (Cichorium intybus L., Asteraceae) were delivered by the Botanical
Garden of Sari University in Iran. The seeds were surface-sterilized by immersion in a sodium hypochlorite solution $(5 \%)$ containing a wetting agent (Tween-20) for $30 \mathrm{~min}$. Seeds were then 
rinsed three times with sterile water and were cultured on MS medium containing $3 \%$ sucrose and $0.8 \%$ plant agar $(\mathrm{pH}=5.7)$ (Murashige and Skoog, 1962). Cultures were grown at $24 \pm 2{ }^{\circ} \mathrm{C}$ and $40 \pm 2 \%$ relative humidity under a $16 / 8 \mathrm{~h}$ photoperiod supplied by cool white fluorescent lighting at an intensity of $68 \mu \mathrm{mol} \mathrm{m}{ }^{2}$ per second.

\subsection{Hairy root induction}

Hairy root induction in $C$. intybus was studied after treatment with various $A$. rhizogenes strains. To determine the best strain, A. rhizogenes A13 (MAFF02-10266), A4, ATCC 15834 and ATCC 11325 were co-cultivated with cotyledon explants of $C$. intybus. Single colonies of A.rhizogenes were inoculated in $10 \mathrm{ml}$ of liquid LB (Luria-Bertani) medium containing $50 \mathrm{mg} \mathrm{l}^{-1}$ kanamycin, and $40 \mathrm{mg} \mathrm{ml}^{-1}$ riphampicin. The cultures were incubated overnight in a rotary shaker at $28 \pm 2{ }^{\circ} \mathrm{C}$ with shaking at $180 \mathrm{rpm}$ in the dark. Three $\mathrm{ml}$ of the overnight culture was used to inoculate $50 \mathrm{ml}$ of LB medium and was grown at the same condition, until an optical density (OD) of $0.3-0.6$ at $600 \mathrm{~nm}$. Then, the bacterial suspension was precipitated at $4500 \mathrm{rpm}$ at $4{ }^{\circ} \mathrm{C}$. The pellet was washed with inoculation medium (half-strength MS medium containing $100 \mu \mathrm{M}$ acetosyringon and $15 \mathrm{~g} \mathrm{l}^{-1}$ sucrose, $\mathrm{pH}$ 5.7) to a final density of OD600 $=0.6$. Seven day-old and well established cotyledon segments of $C$. intybus grown in in-vitro condition were selected and immerged into the bacteria suspension for $2 \mathrm{~min}$. The explants were then dried on sterile filter paper and were inoculated on three different co-culture media at pH 5.7: MS, LS (Linsmaier and Skoog) and B5 (Gamborg et al., 1968). Co-cultivation was prolonged for 48-72 hours to complete T-DNA insertion. The incubation condition was set on $25 \pm 2{ }^{\circ} \mathrm{C}$ in the dark. Following co-cultivation period, the explants were sub cultured on the same media supplemented with $500 \mathrm{mg}^{-1}$ cefotaxime. This step was repeated to eliminate bacterial contamination thoroughly. The samples were screened to find the transformed ones. In order to throw light on the potential of different $A$. rhizogenes strains in hairy root induction, percentages of induced hairy root were counted out of 100 in each treatment group according to the observation of hairy roots development in cotyledon segments.

\subsection{Hairy root growth}

To survey the effect of different culture media on hairy root development, one of the established hairy root systems was cultured in three different media (MS, LS and B5). Ten mm long root tips were transferred to the new media. The cultures were grown at $25{ }^{\circ} \mathrm{C}$ in the dark and constant shaking at $90 \mathrm{rpm}$. Finally hairy root dry mass was recorded after 30 days to determine hair root growth capacity.

\subsection{Bacterial strain and binary vector}

Mikimopine-type A. rhizogenes strain A13 (MAFF02-10266) harboring a wild mikimopinetype Ri plasmid was used to optimize heterogene introduction into the induced hairy roots of $C$. intybus. To investigate the transformation efficiency, pCAMBIA1304 (CAMBIA, Canberra, Australia) binary vector was transferred to A13 strain by the method of Alkaline lysis (Birnboim and Doly, 1979). The pCAMBIA1304 harbor a GUS-mgfp5 fusion reporter under the control of the constitutive cauliflower mosaic virus (CaMV) $35 \mathrm{~S}$ promoter, a selectable marker gene hptII (responsible for hygromycin resistance) and bacterial selectable gene nptII (responsible for kanamycin resistance). The neomycin phosphotransferase II (nptII) was located out of TDNA borders, allowing the kanamycin screening to identify positive transformants of $A$. rhizogenes A13 strain and for elimination of those which lacks the binary vector. Therefore, a concentration of $100 \mathrm{mg} \mathrm{l}^{-1}$ kanamycin was used to select bacterial transformants. Finally, The PCR analysis was conducted using specific primers of the GUS reporter gene to confirm the transgenic bacteria. Forward (5'-ACGTCCTGTAGAAACCCCAA-3' and reverse (5'-CCCGCTTCGAAACCAATGCC3') primers were synthesized by BIOMATIK (BIOMATIK, Canada). PCR amplification of GUS gene was conducted in a Bio-Rad thermocycler through $94{ }^{\circ} \mathrm{C}(5 \mathrm{~min}), 35$ cycles of: $94{ }^{\circ} \mathrm{C}(1 \mathrm{~min})$, $59{ }^{\circ} \mathrm{C}(1 \mathrm{~min})$ and $72{ }^{\circ} \mathrm{C}(1 \mathrm{~min})$ and final extension $72{ }^{\circ} \mathrm{C}$ for $7 \mathrm{~min}$. Amplification products were resolved and visualized on agarose gels. Amplification products were resolved and visualized on agarose gels. 


\subsection{Optimal antibiotic concentration for explant selection}

The efficiency of six different concentrations of hygromycin (Sigma Aldrich, USA) $(0,2.5,5,10$, 20 and $30 \mathrm{mg} \mathrm{l}^{-1}$ ) were studied in order to determine the optimum antibiotic concentration to screen putative explant transformants. The hairy root segments were cultured on MS medium containing the antibiotic for 5 weeks. The hygromycin inhibition test was performed in triplicates for each antibiotic concentration and hairy roots color was monitored to assess the value of mortality i.e., browny roots considered as dead explants.

\subsection{DNA analysis of chicory clones transformed by pCAMBIA1304 Vector}

The survived clones of $C$. intybus on the antibiotic enriched medium were further analyzed using PCR. The aim was done to detect rolB and rolC genes in transformed lines. Total DNA was isolated according to Dellaporta et al. (1983) from the hairy root clones. The following sets of oligonucleotide primers were used to amplify the two genes of interest: rolB: 5GCTCTTGCAGTGCTAGATTT-3 and 5GAAGGTGCAAGCTACCTCTC-3; rolC: 5CTCCTGACATCAAACTCGTC-3 and 5TGCTTCGAGTTATGGGTACA-3. The absence of residual A. rhizogenes was confirmed by PCR detection of virD gene which is outside the T-DNA of $\mathrm{Ri}$ plasmid with specific primers 5ATGTCGCAAGGCAGTAAG-3 and 5CAAGGAGTCTTTCAGCATG-3. DNA amplification reactions were performed under the following thermo cycle conditions: $94{ }^{\circ} \mathrm{C}(5 \mathrm{~min})$, 35 cycles of $95{ }^{\circ} \mathrm{C}(45 \mathrm{~s}), 58{ }^{\circ} \mathrm{C}(30 \mathrm{~s})$ for rolB and rolC and $50{ }^{\circ} \mathrm{C}$ for virD genes and $72{ }^{\circ} \mathrm{C}(1 \mathrm{~min})$, with a final extension step at $72{ }^{\circ} \mathrm{C}$ for $7 \mathrm{~min}$. In order to select the GUS transformed clones, multiplex-PCR using GUS and hptII primers was done on hairy root clones which amplified rol genes. The designed primers to amplify hptII were 5'-CAGTCAATGACCGCTGTTATG-3' and 5'AGACCTGCCTGAAACCGAACT-3'. Fifty nanograms of template DNA and $1 \mu \mathrm{l}$ of $10 \mathrm{pmol}$ $\mu l^{-1}$ primer were mixed with $2.5 \mu 1$ of $10 \mathrm{X}$ PCR buffer, $0.5 \mu 1$ of $10 \mathrm{mM}$ dNTP mixture (equimolar dATP, dCTP, dGTP, dTTP), $1 \mu$ of $50 \mathrm{mM} \mathrm{MgCl}_{2}$ and $0.2 \mu \mathrm{l}$ of taq DNA polymerase (Fermentas, Vietnam) $\left(5 \mathrm{U} \mathrm{\mu l}^{-1}\right)$ in a total volume of $25 \mu \mathrm{l}$.
Plasmid DNA from A. rhizogenes strain A13 was used as a positive control and natural roots of chicory were used as negative control. The expected PCR products were $430 \mathrm{bp}$ for rolB, 612 bp for rolC and $430 \mathrm{bp}$ for hptII genes. The amplification products were separated by $1.5 \%$ agarose gel electrophoresis, stained with ethidium bromide and photographed.

\subsection{GUS histochemical assay}

Hairy roots were subjected to X-glucuron treatment according to the method by Jefferson et al. (1987). Ten days after co-cultivation, roots were immersed in sodium phosphate buffer $(50 \mathrm{mM}$ and $\mathrm{pH}$ 7.0) containing $2 \mathrm{mM}$ 5- bromo-4-chloro-3indolyl- $\beta$-glucoronic acid (X-Gluc). The reaction was allowed to proceed for $20 \mathrm{~h}$ in the dark at $37^{\circ} \mathrm{C}$. GUS-expressing cells were detected microscopically by the distinct blue color that developed as a result of enzymatic cleavage of Xglucuronide.

\subsection{Callus induction and regeneration capability}

Transgenic hairy roots harboring the GUS gene were cultured on solid MS medium containing different plant growth regulators (PGRs); combinations of benzyladenine (BA) $(0.2,0.5$, $\left.1 \mathrm{mg} \mathrm{l}^{-1}\right)$ and naphthalene acetic acid (NAA) $(0.2$, $\left.0.5 \mathrm{mg} \mathrm{l}^{-1}\right)$ and also BA $\left(0.2,0.5 \mathrm{mg}^{-1}\right)$ and 2,4-D $\left(0.5,1,2 \mathrm{mg} \mathrm{l}^{-1}\right)$ were supplemented into the callus-inducer medium. The samples were incubated at $25 \pm 2$ in the dark for 4 weeks for callus induction.

Hairy root calli derived from different PGRs were subcultured in regeneration medium containing various PGRs, i.e. BA $\left(0.2,0.5,1 \mathrm{mg} \mathrm{l}^{-1}\right)$ and IBA $\left(0.2,1 \mathrm{mg} \mathrm{l}^{-1}\right)$ and also BA $\left(0.2,0.5,1 \mathrm{mg} \mathrm{l}^{-1}\right)$ and NAA $\left(0.1,0.5 \mathrm{mg} \mathrm{l}^{-1}\right)$. The effect of callus inducer medium on regeneration capability was lately studied.

\subsection{Statistical analysis}

All the experiments were set up in a completely randomized design (CRD) with three replicates per treatment. Data expressed as mean $\pm \mathrm{SD}$ and the means were compared using one-way ANOVA and statistical significance of result measured by using Duncan's multiple range, Posthoc test $(\mathrm{P}=0.05)$. 
The statistical analyses were performed using the statistical package SPSS (Statistical Package for Social Science; version 17). Further analyses and also design graphs were done using Microsoft Excel 2010.

\section{RESULTS AND DISCUSSION}

\subsection{Comparison of different bacterial strains and medium effect on transformation efficiency}

Selection of the most effective bacterial strains by desired growth and virulence phenotypes have a significant impact on final explant transformation efficiency (Lee et al., 2010). Moreover, it has been previously confirmed that selection of appropriate medium before clone propagation stage has a significant impact upon the final efficiency of a commercial hairy root system (Pakdin and Farsi, 2013). Our results showed that the rates of transformation (were $63.15 \%, 36.47 \%, 18.2 \%$ and $0 \%$ for $\mathrm{A} 13, \mathrm{~A} 4,15834$ and 11325 strains respectively (Fig. 1). Transformation rates were calculated based on hairy roots' emergence and accordingly, 11325 strain did not induce any hairy root in the studied media. In all studied media, results showed that MS was the most suitable cultivation medium for hairy root induction and B5 was the least suitable. Finally we realized that the combination of A13 strain and MS medium is the best transformation for $C$. intybus hairy roots. Hairy root induction frequencies in different plant species by different $A$. rhizogenes strains is various and the ability of $A$. rhizogenes to infect plant species are strain dependent (Porter R, 1991; Sharafi et al., 2013). Similar studies were made on comparison of hairy root induction by different strains of A. rhizogenes. A4 and A13 strains showed highest efficiency in hairy root induction in Solanum mammosum L. which were $21.41 \pm$ $10.60 \%$ and $21.43 \pm 8.13 \%$ respectively (Ooi et al., 2013). In another study, hairy root induction frequencies in Dracocephalum kotschyi Boiss. was $52.3 \%, 69.6 \%, 48.6 \%, 89.0 \%$, and $80.0 \%$ using A4, A13, LBA9402, MSU440, and ATCC15834 strains, respectively (Sharafi et al., 2014).

However, a range of parameters including explant type, OD600 value of the A. rhizogenes cell culture, duration of co-cultivation, $\mathrm{pH}$ of cocultivation medium and temperature during cocultivation were previously evaluated in $A$. rhizogenes-mediated transformation (Henzi et al, 2000; Cao et al, 2009), but there are only few reports on the effect of the medium on the initiation of hairy roots after co-cultivation (Pakdin and Farsi, 2013; Bivadi et al., 2014). Our results, as shown in the Figure 1, show that induction medium had a significant effect on the ability of different $A$. rhizogenes strains for hairy root induction. MS medium with $45.34 \%$ of root induction was the best combination for inducing of chicory hairy roots in all strains, LS and B5 medium with $35.94 \%$ and $22.22 \%$ respectively, were less effective. The induction frequencies of A13 and A4 in the LS and MS medium were not significantly different nonetheless, A13 showed the highest ability in MS medium. The results indicated that the effects of the induction media, $A$. rhizogenes strain and their interaction, were significant $(p<0.05)$. The presence of interaction between culture media and $A$. rhizogenes strains illustrates that the hairy root induction ability of different A. rhizogenes strains is related to the induction medium. Pakdin et al. (2013), investigated hairy root induction in Valeriana officinalis L. using various A. rhizogenes strains, A4, ATCC 15834, ATCC 11325 and A13 along with three different induction media, half strength MS, Gamborg's B5 and LS Data showed that A4 had the greatest transformation frequency $(54 \%)$ in LS medium, while the best medium for ATCC 15834 was $1 / 2$ MS with $40.67 \%$ efficiency. ATCC 11325 showed a similar transformation frequency $(9.67 \%)$ in both $1 / 2$ MS and LS media, but did not induce any hairy root in B5 medium and A13 did not induce hairy root at all (Pakdin and Farsi, 2013). Bivadi et al. (2014) reported that in full strength MS and $1 / 4$ MS medium, the transformation rate in Hypericum perforatum $\mathrm{L}$. were $64.66 \%$ and $47.30 \%$, whereas in $1 / 2$ MS and B5 the transformation rate were $78 \%$ and $86.33 \%$ respectively. In another study, maximum transformation frequency of tested bacterial strain K599 on Glycyrrhiza glabra L. was $47 \%$ obtained in 3 weeks old explants on MS basal semi solid medium (Mehrotra et al., 2008). During this study, 
NB and B5 media showed only $20 \%$ for transformation frequency. Moreover, WP medium did not support any induction of hairy roots in cultured leaf explants infected even after 50 days of incubation. These results indicate that selection of Agrobacterium strain and media conditions for co-cultivation is plant-species dependent and should be examined before transformation.

Given the pathogenicity severity of A13 strain compared to the other strains (more than $27 \%$ more successful than the A4 strain), and also regarding to the growth rate of induced hairy root clones, A13 strain was selected for gene cassette transformation. Fortunately, interaction of A13 strain and MS medium successfully enhanced hairy root induction efficiency. Sensitivity of A13 strain to rifampicin and kanamycin had made easier the screening of plasmid-harboring bacteria in comparison with other agrobacterium strains.

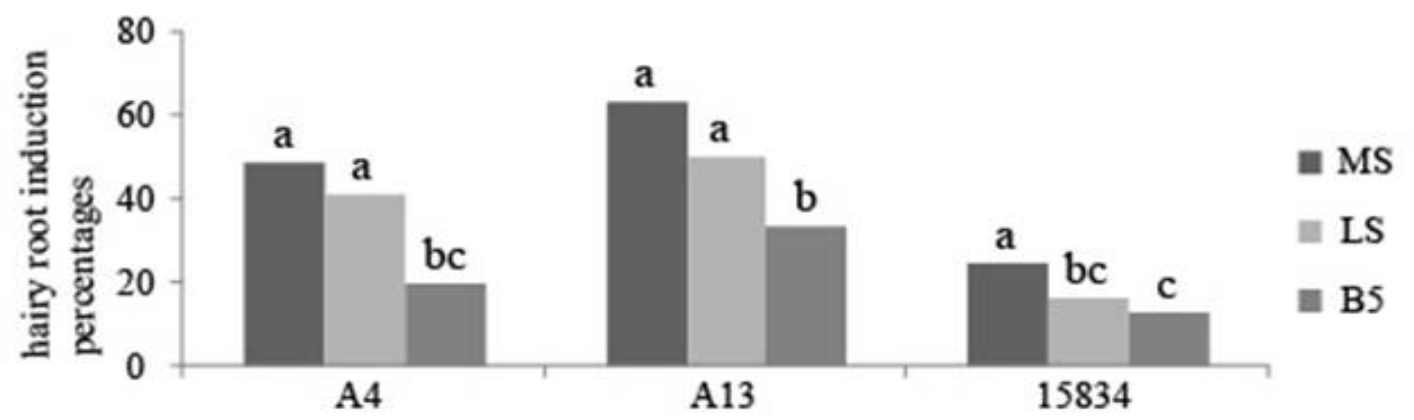

Figure 1: Comparison of different combinations of plant tissue culture media and A. rhizogenes strains on hairy root induction of chicory. Results are the mean of three replicates \pm SD for percentages of induced hairy roots. Means with the same letter are not significantly different $(p>0.05)$.

\subsection{Comparison of different media and bacterial strain on hairy root growth}

The influence of nutrient supplementation through different culture media on the dry mass of hairy roots was determined. Based on the obtained results, MS medium affected the hairy root growth and dry mass positively; on the contrary, B5 medium provided the poorest condition for the hairy root development and consequently brought the least dry mass. In more details and according to the Table 1, accumulation of dried hairy roots biomass in MS medium which was infected by A13 strain was $1.10 \mathrm{~g} \mathrm{l}^{-1}$ which was significantly higher than those grown in LS and B5 medium 0.88 and $0.72 \mathrm{~g} \mathrm{l}^{-1}$, respectively $(\mathrm{P}=0.05)$. Hence, MS medium was considered as the best medium for transgenic hairy root growth in following steps.

Maximum accumulation of biomass was recorded for hairy roots induced by A13 strain $\left(1.10 \mathrm{~g} \mathrm{l}^{-1}\right)$ in MS medium. In contrary, minimum dry mass of hairy roots was induced by A4 strain $\left(0.05 \mathrm{~g}^{-1}\right)$ in B5 medium (Table 1). Moreover, the interaction of variant hairy root-inducing bacterial strains with different culture media has been studied. Generally, the hairy roots induced by A13 strain present the highest dry mass of produced hairy roots, regardless of the cultivation medium. On the other hand, the effect of medium type on growth of hairy root induced by A4 stain was statistically significant in all different media. In brief, hairy roots growth was at least in B5 medium and the best records were observed in MS medium (Fig. 2).

These results were in line with previously published studies, e.g. B5 and $1 / 2$ B5 media were the best basal media for hairy root growth of $V$. officinalis (Pakdin et al., 2014) and the NB medium composition supported best growth of hairy roots in Glycyrrhiza glabra followed by MS, B5 and WP media (Mehrotra et al., 2008). In G. glabra 20 times increase in root biomass on fresh mass basis was recorded after 45 days of culture in NB medium. Thus, it is clear that transformation frequency, hairy root induction and biomass accumulation are strain specific characteristics and are strongly affected by explants age and media ingredient (Sarma et al., 1997). 
Table 1: Comparison of different combinations of plant tissue culture media and A. rhizogenes strains on hairy root dry mass. Results are the mean of three replicates for dry mass of induced hairy roots in Cichorium intybus. Means with the same letter are not significantly different $(p>0.05)$.

\begin{tabular}{lll}
\hline Medium & Strain & Dry mass $\left(\mathbf{g ~}^{-1}\right)$ \\
\hline & A13 & $1.10^{\mathrm{A}}$ \\
MS & A4 & $0.73^{\mathrm{B}}$ \\
& 15834 & $0.34^{\mathrm{C}}$ \\
LS & A13 & $0.88^{\mathrm{AB}}$ \\
& A4 & $0.48^{\mathrm{C}}$ \\
& 15834 & $0.43^{\mathrm{C}}$ \\
B5 & A13 & $0.72^{\mathrm{B}}$ \\
& A4 & $0.05^{\mathrm{E}}$ \\
\hline
\end{tabular}

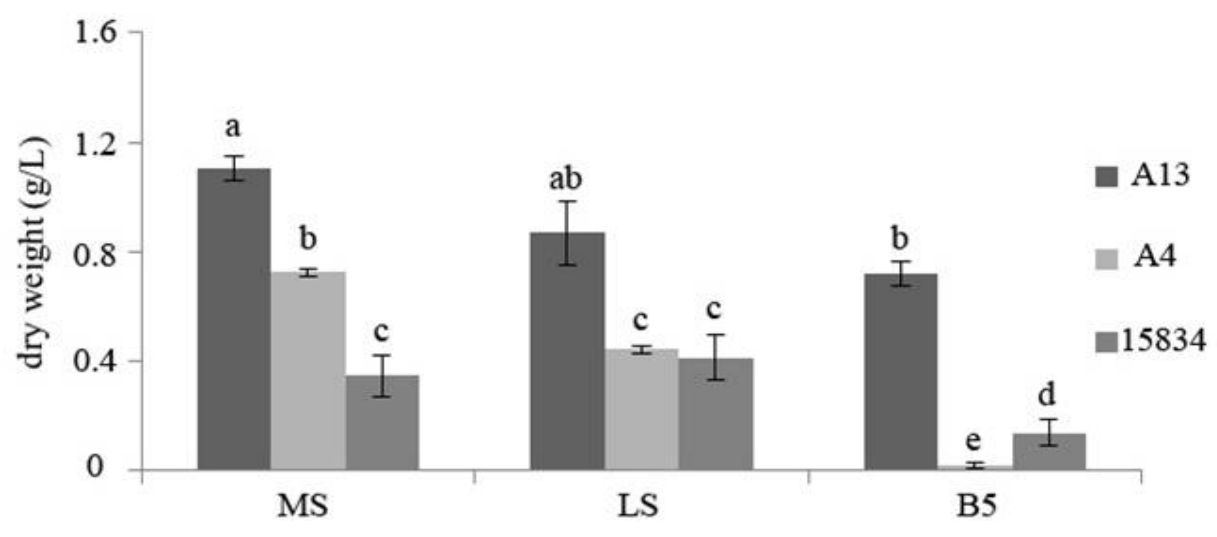

Figure 2: A comparison of the effects of different combinations of Agrobacterium strains and plant tissue culture media on dry weight of chicory hairy roots. The mean of three replicates \pm SD for percentages of emerged hairy roots were calculated and those with the same letter are not significantly different $(p>0.05)$.

\subsection{Molecular confirmation of transformed bacteria}

Amplification of a 1098 bp fragment by PCR using specific GUS primers indicates the presence of the GUS sequence and also desired plasmid in selected colonies appeared on the selective medium (Fig. 3). Lack of GUS amplification in non-transgenic bacteria as a negative control and its amplification in extracted plasmid as a positive control had confirmed the plasmid transformation. Beside, in order to examine the expression of transferred reporter gene, GUS expression assay was performed. Transformed Escherichia coli $\mathrm{T}$. Escherich, 1885 harboring pCAMBIA1304 vectors were stained for GUS activity with GUS staining solution. Appearance of blue color via x-Gluc hydrolysis approved the successful transformation and expression of GUS gene in T-DNA fragment of 1304 vector (Fig. 6.a).

Bacterial uid A gene encoded GUS, regarded as the most widely used reporter gene for gene expression in plants (Resmi et al., 2005). GUS consumes and brakes glucuronide as substrate, leading to a color reaction so that its presence is visible. As expected, culture medium containing bacteria, turned blue after 18 hours in staining solution that indicated GUS expression. Moreover, PCR with specific primers of rol B and C genes was conducted on extracted DNA from the selected colonies. Amplification of the fragments with approximate length of $430 \mathrm{bp}$ for rol B and $612 \mathrm{bp}$ for rolC genes confirmed the hairy root inducing characteristic of the suspected colonies (Fig. 4). 


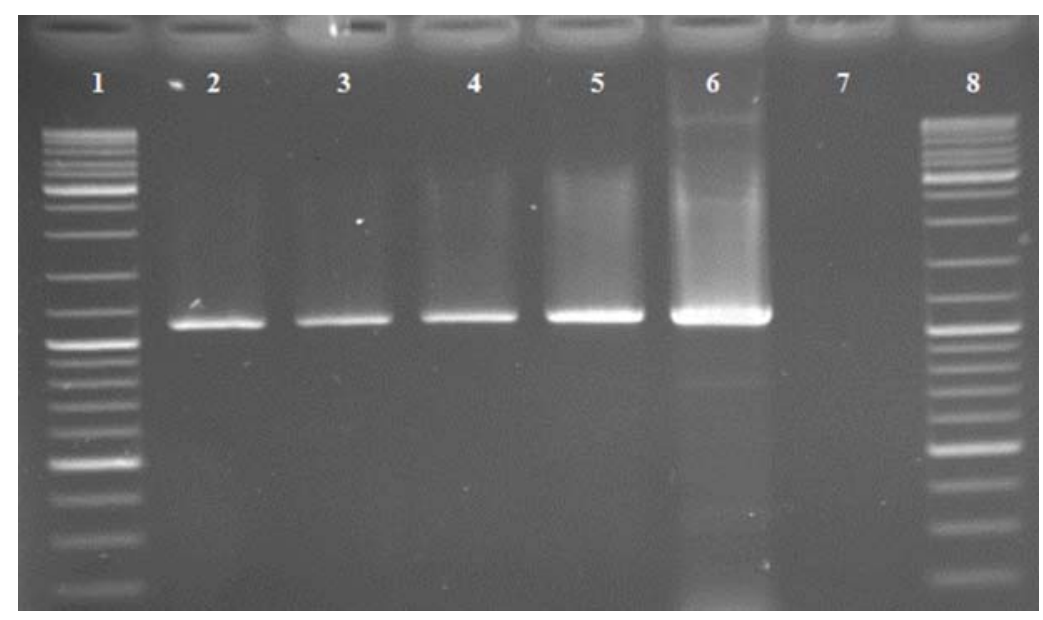

Figure 3: PCR analysis results of GUS gene in colonies of A13 strain: 1-Size marker (Fermentas SM0331), 2-4: Fragments amplified from Agrobacterium A13 strain single colonies 1 to 3, 5-Amplified fragment from E. coli harboring 1304 plasmid, 6-Amplified fragment from isolated plasmid pCAMBIA 1304 used as a positive control, 7- Absence of amplification fragment in empty A13 strain without the plasmid pCAMBIA 1304, 8-Size marker (Fermentas SM0331)

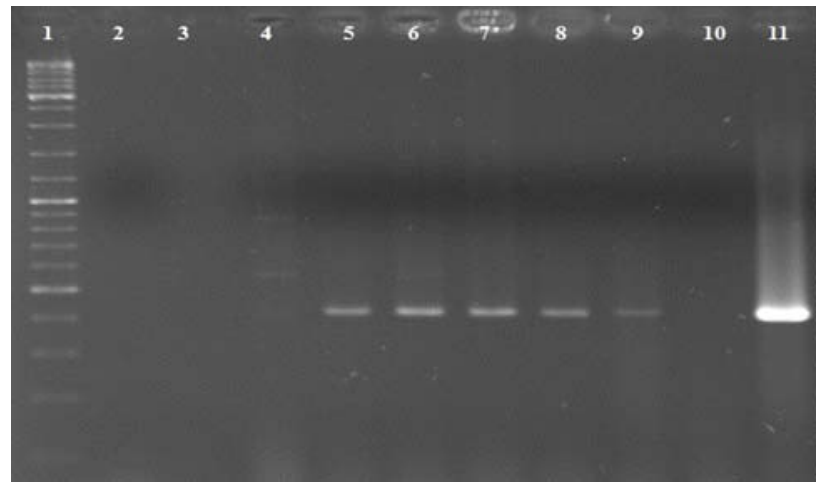

Figure 4: PCR analysis results of rol B gene: 1- Size marker (Fermentas SM0331), 2-4- Absence of fragment from non-transformed root clone derived DNA, 5-9- Amplified fragments from DNA isolated from hairy roots treated with A13,10- Absence of fragment from DNA isolated from un-treated root, 11- Amplified fragment from DNA isolated from A. rhizogenes strain A13.

\subsection{Molecular confirmation of C. intybus transformed lines}

3.4.1 Selection of putative clones using
hygromycin

In order to screen transgenic explants and determine minimum selective concentration, both transfected and control explants were grown in solid MS medium containing different concentrations of hygromycin $(0,2.5,5,10,20,30$ $\left.\mathrm{mg} \mathrm{I}^{-1}\right)$. Non-transgenic roots grown only at concentrations lower than $5 \mathrm{mg} \mathrm{l}^{-1}$. Roots on increased the concentrations of hygromycin led roots to turn black and finally died, therefore
$5 \mathrm{mg} \mathrm{l}^{-1}$ was chosen as the selective concentration. Thus, roots were selected after growing in selective medium and further were subcultured in liquid MS medium. In a study on Lotus corniculatus L., the authors reported $4 \mathrm{mg} \mathrm{l}^{-1}$ of hygromycin as the best concentration for transformed line screening (Bo et al., 2009). As another example, transformed Prunus domestica L. was selected in $5 \mathrm{mg} \mathrm{l}^{-1}$ of hygromycin (Lining et al., 2009).

\subsubsection{DNA analysis of hairy roots}

To survey the stable transformation of hairy roots, amplification of rol genes with two specific primers was performed using genomic DNA 
extracted from survived hairy root clones. The hairy roots were induced by $A$. rhizogenes harboring $\mathrm{Ri}$ plasmid and binary vector, pCAMBIA1304. The explants were further screened in medium enriched with $5 \mathrm{mg}^{-1}$ hygromycin. The results of the separation of PCR amplified products and fragments detection confirmed the presence of two rol B (430 bp) (Fig. 4) and rol C (612 bp) genes in the genome of the hairy root cells (Krolicka et al., 2001). To verify the absence of residual $A$. rhizogenes infection on hairy roots, the vir D gene outside the T-DNA region of Ri plasmid was also studied. A putative size of PCR product for vir D was only amplified from the colony of $A$. rhizogenes and no product was obtained using DNA from any of the studied hairy root samples. The findings clearly confirmed that the hairy roots were not contaminated by $A$. rhizogenes.

Similar investigation was done using multiplexPCR reactions with specific primers of GUS and hptII genes. Among 20 putative transgenic hairy root clones, from 13 clones we positively amplified a fragment with 1098 bp length with the GUS primers. Four clones amplified the hygromycin gene segment with $430 \mathrm{bp}$ length and a total of four clones were positive for both reporter genes by PCR. The electrophoresis pattern is shown in Figure 5. It indicates the introduction of binary vector T-DNA and Agrobacterium Ri plasmid TDNA into genome of studied roots.

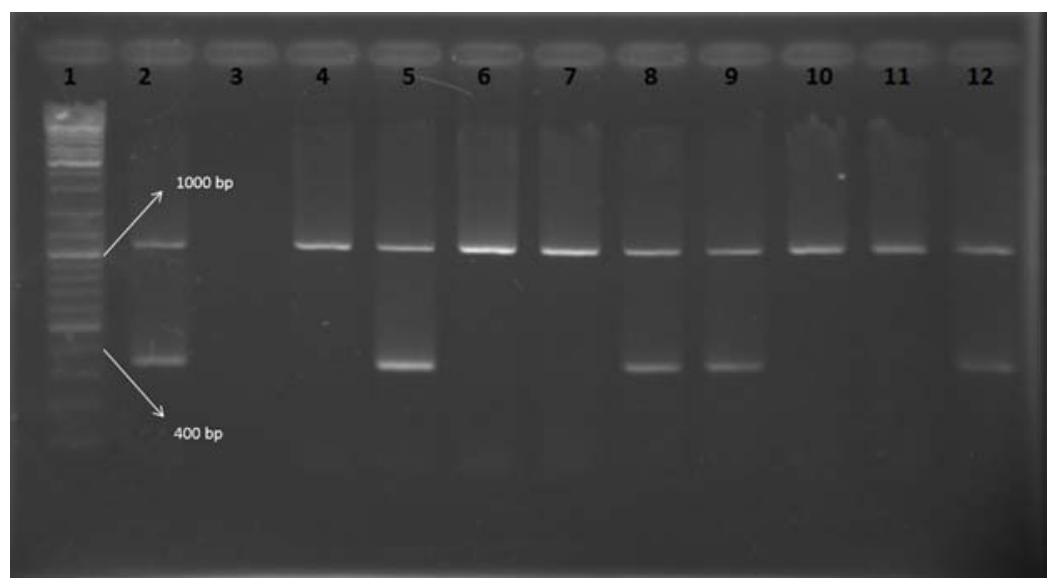

Figure 5: Hygromycin and GUS gene duplex PCR analysis results: 1-Size marker (Fermentas SM0331), 2Amplified fragment from isolated plasmid pCAMBIA 1304 as positive control, 3- Absence of amplified fragment from non-transformed hairy roots, 4-6-7-10-11-Amplified fragments from transgenic hairy roots derived DNA that received only GUS gene, 5-8-9-12-Amplified fragments from transgenic hairy roots derived DNA that received both GUS and hygromycin genes.

\subsection{GUS staining assay}

To investigate Uid A gene expression, the samples which present positive amplification for both reporter genes were further analyzed using GUS histochemical assay. Blue color development induced by beta-glucuronidase reporter gene expression was observed in two transgenic hairy root clones, after histochemical staining. Only the tip of hairy roots became blue in clone 8 (Fig. $6 \mathrm{~d}$ ) and in clone 21 , the entire root was in blue color after histochemical staining (Fig. $6 \mathrm{f}$ and $\mathrm{g}$ ). Explanation for this pattern may be a response to the powerful activity of the CaMV $35 \mathrm{~S}$ promoter in the vascular tissue which in turn result in accumulation of blue dots in root tips where are mitotically active sites. The reason of the GUS expression only in tip of the clone 8 is that is the most active in, as was found with bell pepper leaf like structures and also in the mitotic root tip (Yamakawa et al., 1998). This pattern of expression is consistent with previous results for GUS gene expression directed by the CaMV 35S promoter (Jefferson et al., 1987). The color after staining indicates successful transformation and expression of GUS reporter gene from $A$. rhizogenes in hairy roots of the chicory plant. Interestingly the growth rate of the clone No. 21 was lower than other clones. This observation was in line with the results of a study conducted in 
transformation of phenylalanine ammonia-lyase (PAL) using A13 strain of A. rhizogenes to Capsicum frutescens L. (Yamakawa et al., 1998). In this study the morphology and growth rate of transgenic roots harboring pal gene varied from non-transgenic roots, growth rate of root was lower than in non-transgenic roots and the diameter was 3 times higher. Results showed that the GUS transformation and expression by A13 strain was highly stable because GUS expression was observed even a year after transformation and this indicates the stability of GUS transformation and expression and also insertion of the gene in to the plant genome and non-occurrence of methylation, deletion or mutation. The efficiency of transformation was estimated about $10 \%$ in $C$. frutescens (Tamakawa et al., 1998) and 5 to $10 \%$ in gene transformation using A. rhizogenes strain A13 in Vaccaria pyramidata Medik. (Masaaki et al., 2000).

\subsection{Transgenic hairy root regeneration}

Transgenic hairy roots cultured in callus induction medium were able to produce callus under the influence of all hormonal components. Production, development and friability of callus were significantly higher in medium containing 2, 4-D hormone and clearly increased with increased concentrations of 2, 4-D up to $2 \mathrm{mg} \mathrm{l}^{-1}$. After 8 weeks of growth in callus induction medium, calluses were transferred to regeneration medium. The produced calluses in all culture medium containing 2, 4-D were not able to develop green color in any of the regeneration medium and no color changes were observed after two months (Fig. 6jk). In other treatments containing (BA) $\left(0.2,0.5,1 \mathrm{mg} \mathrm{l}^{-1}\right)$ and NAA $\left(0.2,0.5 \mathrm{mg} \mathrm{l}^{-1}\right)$, callus turned green as a sign of regeneration. The synergistic effect of NAA $0.5 \mathrm{mg} \mathrm{l}^{-1}$ and BA $0.5 \mathrm{mg} \mathrm{l}^{-1}$ showed a greenish white callus whereas higher concentrations of BA along with NAA $0.5 \mathrm{mg} \mathrm{l}^{-1}$ produced a green colored callus. Whitish green and green color calli were developed under the influence of higher concentrations of BA. Growth of callus originated from hairy roots and also root pieces were reduced with increasing concentrations of applied cytokinin BA. At lower concentrations of BA (lower than $1 \mathrm{mg} \mathrm{l}^{-1)}$ hairy roots and callus continued their rapid growth and concentration $1 \mathrm{mg}^{-1}$ of $\mathrm{BA}$ prevented callus growth. Although some transgenic hairy root calluses showed early stages of regeneration, such as the formation of a hard, compact and green callus, after two months chicory shoots development was not observed in any of the treatments (Fig. 61).

According to the obtained results and previously published reports describing hairy root regeneration, lack of hairy roots regeneration in chicory were attributed to insufficient concentrations of growth regulators in the medium (especially cytokinin hormone). Therefore to achieve a desirable rate of regeneration, green callus could be sub-cultured into MS medium containing high concentrations of cytokinin (2-4 $m g 1^{-1}$ BA or kinetin) in combination with low concentrations of auxin (0.5-1 $\mathrm{mg}^{-1} \mathrm{NAA}$ or IAA). Based on our observations, after 8 weeks, the green color of callus tissue developed and the growth of hairy roots almost stopped. However, although the early stages of regeneration were observed in cultures, none of the applied treatments induced regeneration in transgenic chicory.

Several reports have provided details of plant regeneration from hairy roots of various species (Han et al., 1993; Choi et al., 2004). Plantlets regenerate directly from transgenic hairy roots after transferring to hormone-containing medium. For example shoot regeneration was promoted from hairy roots of Robinia pseudoacacia L. cultured in medium containing $10 \mu \mathrm{mol} 1^{-1}$ NAA and $5 \mu \mathrm{mol}^{-1}$ BAP (Han et al., 1993).

Moreover, transgenic roots can produce somatic embryos by adding appropriate plant growth regulators, e.g., Cho and Wildholm (2002) reported that plant hairy roots of Astragalus sinicus L. were developed to somatic embryos in media containing 7.5-10 $\mathrm{mg}^{-1} 2$, 4-D. Chicory plants regeneration from hairy roots have been reported by Harsh et al. (2001). According to this study, supplementation of (4 BA and 1 NAA mg $~^{-1}$ ) was considered as the best motive agent for regeneration. In our study despite applying the before mentioned concentrations, no regeneration was observed, this may be caused by difference in the type of the strain used for induction of hairy roots or due to the location of T-DNA insertion into the plant genome. Unsuccessful shoot regeneration from hairy root has also been reported; Guellec et al. 
(1990) failed to induce plant regeneration from transformed roots of Vitis vinifera L. obtained by

\section{A. rhizogenes-mediated transformation.}
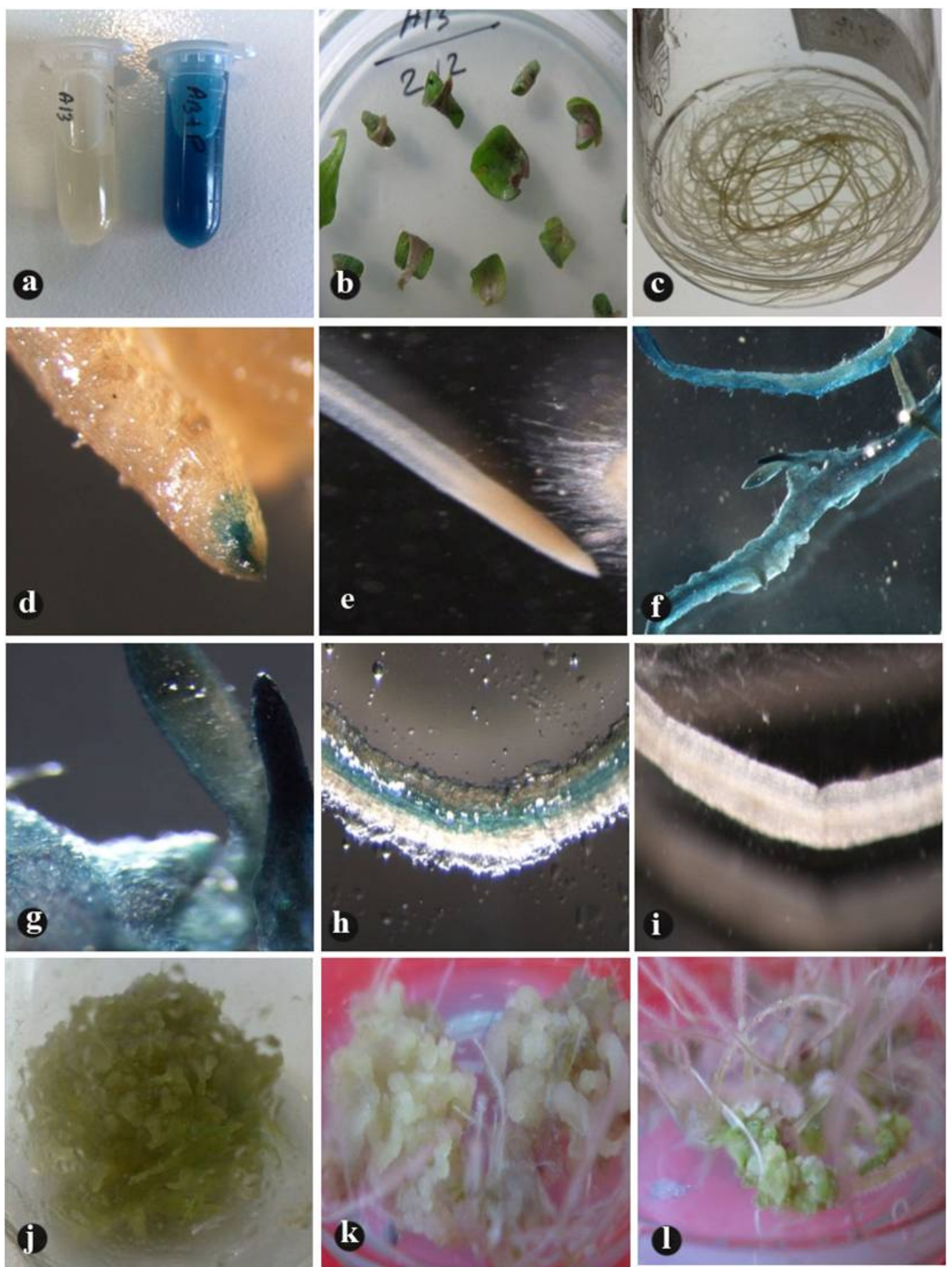

Figure 6: GUS expression in chicory hairy root. (a) Histochemical GUS staining of transgenic bacteria (right) and lack of GUS expression in non-transgenic bacteria (left), (b) Chicory cotyledon in MS co-cultivation medium, (c) Hairy root induced by A13 strain in liquid MS medium, (d) Transient GUS expression in tip of the root clone 8, (e) Lack of GUS expression in non-transgenic roots, (f, g) GUS expression in clone 21, (h) GUS expression in hairy root vascular tissue, (i) Lack of expression in non-transgenic root vascular tissue, (j) Hairy root callus developed on MS regeneration medium supplemented with $1 \mathrm{mg} \mathrm{l}^{-1}$ IBAand $0.5 \mathrm{mg} \mathrm{l}^{-1} \mathrm{BA}$, (k) Hairy root callus developed on MS regeneration medium supplemented with 0.1 NAA and $0.5 \mathrm{BA} \mathrm{mg}^{-1}$ (l) Hairy root callus developed on MS regeneration medium supplemented with 1NAA and 4 BA $\mathrm{mg} \mathrm{l}^{-1}$. 


\section{CONCLUSION}

As described in the introduction, chicory (Cichorium intybus) has received much attention in Persian/Chinese traditional medicine. We propose that an efficient transformation techniques could contribute not only to basic studies but also to the molecular breeding of chicory using various genetic resources. Moreover, secondary metabolite secretion using chicory hairy root platform could serve pharmacological application in which an optimized pre-step cultivation would end to a successful process.

\section{ACKNOWLEDGMENTS}

This research was financially supported by the Genetic and Agricultural Biotechnology Institute of Tabarestan (GABIT).

\section{REFERENCES}

Bais. HP., Govindaswamy. S., Ravishankar. GA. (2000). Enhancement of growth and coumarin production in hairy root cultures of witloof chicory (Cichorium intybus L. cv. Lucknow local) under the influence of fungal elicitors. Journal of bioscience and bioengineering, 90: 648-653. DOI: 10.1016/S1389-1723(00)90011-2

Birnboim. HC., Doly. J. (1979). A rapid alkaline extraction procedure for screening recombinant plasmid DNA. Nucleic Acids Res, 7: 1513-1523. DOI: $10.1093 /$ nar/7.6.1513

Bivadi. V., Asghari. ZR., Zare. N., Yazdani. B. (2014). Effects of different tissue culture conditions in Hairy roots induction in Hypericum perforatum L. International Research Journal of Applied and Basic Sciences, 8: 597-604.

Bo. J., Wensheng. H., Cunxiang. W., Bin. L., Wei. L., Shikui. S., Yurong. B., Tianfu. H. (2009). Agrobacterium rhizogenes-mediated transformation of Superroot derived Lotus corniculatus plants: a valuable tool for functional genomics. BMC Plant Biology, 9: 78. DOI: 10.1186/1471-2229-9-78

Cao. D., Hou. W., Song. S., Sun. H., Wu. C., Gao. Y., Han. T. (2009). Assessment of conditions affecting Agrobacterium rhizogenes-mediatedtransformation of soybean. Plant Cell Tissue Organ Cult, 96: 4552. DOI: $10.1007 / \mathrm{s} 11240-008-9458-\mathrm{x}$

Cho. HJ., \& Wildholm. JM. (2002). Improved shoot regeneration protocol for hairy roots of the legume Astragalus sinicus. Plant Cel Tiss Org Cult 69: 259-269. DOI: 10.1023/A:1015624316573

Choi. PS., Kim. YD., Choi. KM., Chung. HJ., Choi. DW., Liu. JR. (2004). Plant regeneration from hairy-root cultures transformed by infection with Agrobacterium rhizogenes in Catharanthus roseus. Plant Cell, Rep 11: 828-831. DOI: 10.1007/s00299004-0765-3

Daimon. H., Fukami. M., Mii. M. (1990). Hairy root formation in peanut by the wild type strains of Agrobacterium rhizogenes. Plant Tissue Cult Lett, 7: 31-34. DOI: 10.5511/plantbiotechnology1984.7.31

Dellaporta. SL., Wood. J., Hicks. JB. (1983). A plant DNA minipreparation version II. Plant Molecular Biology Reporter, 1: 19-21. DOI: 10.1007/BF02712670

Gamborg. OL., Miller. RA., Ojima. K. (1968). Nutrient requirement of suspension cultures of soybean root cells. Exp Cell Res, 50: 151-158. DOI: 10.1016/0014-4827(68)90403-5

Giri. A., \& Narasu. M. L. (2000). Transgenic hairy root. recent trends and application Biotechnology advances, 18: 1-22. DOI: 10.1016/S07349750(99)00016-6

Guellec. V., David. C., Branchard. M., Tempe. J. (1990). Agrobacterium rhizogenes mediated transformation of grapevine Vitis vinifera L. Plant Cell, Tissue and Organ Culture, 24: 91-5 .

Han. K. H., Keathley. D. E., Davis. J. M., Gordon. M. P. (1993). Regeneration of a transgenic woody legume (Robinia pseudoacacia L. blacklocust) and morphological alterations induced by Agrobacterium rhizogenes-mediated transformation. Plant Sci, 88: 149-157. DOI: 10.1016/0168-9452(93)90086-F 
Harsh. P. B., Venkatesh. R. T., Chandrashekar. A., Ravishankar. G. A. (2001). Agrobacterium rhizogenes-mediated transformation of Witloof chicory in vitro shoot regeneration and induction of flowering. Current science, 80: 83-87.

Henzi. M. X., Christey. M. C., McNeil. D. L. (2000). Factors that influence Agrobacterium rhizogenesmediated transformation of broccoli (Brassica oleracea L. var. italic. Plant Cell Reports, 19: 994999. DOI: $10.1007 / \mathrm{s} 002990000221$

Jefferson. R. A., Kavanagh. T. A., Bevan. M. W., (1987). GUS-fusions: b-glucuronidase as a sensitive and versatile gene fusion marker in higher plants. EMBO J, 6: 3901-3907.

Karimi. M. H., Ebrahimnezhad. S., Namayandeh. M., Amirghofran. Z. (2014). The effects of Cichorium intybus extract on the maturation and activity of dendritic cells. Daru, 22: 28-34. DOI: 0.1186/20082231-22-28

Kastell. A., Smetanska. I., Ulrichs. C., Cai. Z., Mewis. I. (2013). Effects of phytohormones and jasmonic acid on glucosinolate content in hairy root cultures of Sinapis alba and Brassica rapa. Applied biochemistry and biotechnology, 169: 624-635. DOI: $10.1007 / \mathrm{s} 12010-012-0017-\mathrm{X}$

Krolicka. A., Stanszewska. I., Bielawski. K., Malinski. E., Szafranek. J., Lojkowska. E. (2001). Establishment of hairy roots of Ammi majus. Plant Science, 160: 259-264. DOI: 10.1016/S01689452(00)00381-2

Lee. M. H., Yoon. E. S., Jeong. J. H., Choi. Y. E. (2004). Agrobacterium rhizogenes-mediated transformation of Taraxacum platycarpum and changes of morphological characters. Plant Cell Reports, 22: 822-827. DOI: 10.1007/s00299-0040763-5

Lee. S. Y., Kim. S. G., Song. W. S., Kim. Y. K., Park. N., Park. S. U. (2010). Influence of different strains of Agrobacterium rhizogenes on hairy root induction and production of alizarin and purpurin in Rubia akane Nakai. Romanian Biotechnol Lett, 15: 5405-5409.

Lining. T., Fatih. A. C., Xinhua. W., Susan. S. (2009). Genetic transformation of Prunus domestica L. using the hpt gene codingfor hygromycin resistance as the selectable marker. Scientia Horticulturae, 119: 339-343. DOI: 10.1016/j.scienta.2008.08.024

Linsmaier. E. M., \& Skoog. F. (1965). Organic growth factor requirement of tobacco tissue cultures. Physiol. Plant, 18: 100-127. DOI: 10.1111/j.13993054.1965.tb06874.x
Malarz. J., Stojakowska. A., Kisiel. W. (2002). Sesquiterpene lactones in a hairy root culture of Cichorium intybus. Z Naturforsch C, 57: 994-997. DOI: $10.1515 /$ znc-2002-11-1207

Masaaki. K., Hirashima. K., Nakahar. T. (2000). Genetic Transformation in Vaccaria pyramidat Using Agrobacterium rhizogenes. Plant Biotechnology, 17: 163- 166. DOI: 10.5511/plantbiotechnology.17.163

Mehrotra. S., Arun. K. K., Suman. P., Singh. K., Bhartendu. N. M. (2008). Genetic transformation studies and scale up of hairy root culture of Glycyrrhiza glabra in bioreactor. Electronic Journal of Biotechnology, 11: 1-7. DOI: 10.2225/vol11issue2-fulltext-6

Murashige. T., \& Skoog. F. (1962). A revised medium for rapid growth and bioassays with tobacco tissue cultures. Physiol Plant, 15: 473-497. DOI: 10.1111/j.1399-3054.1962.tb08052.x

Nandagopal. S., \& Kumari. B. R. (2007). Phytochemical and antibacterial studies of Chicory (Cichorium intybus L.)-A multipurpose medicinal plant. Advances in Biological Research, 1: 17-21.

Ooi. C. T., Syahida. A., Stanslas. J., Maziah. M. (2013). Efficiency of different Agrobacterium rhizogenes strains on hairy roots induction in Solanum mammosum. World Journal of Microbiology and Biotechnology, 29: 421-430. DOI: 10.1007/s11274012-1194-z

Otani. M., Mii. M., Handa. T., Kamada. H., Shimada. T. (1993). Transformation of sweet potato (Ipomoea batatas (L.) Lam.) plants by Agrobacterium rhizogenes. Plant Sci, 94: 151-159. DOI: 10.1016/0168-9452(93)90016-S

Pakdin. A., Farsi. M., Nematzadeh. G. A., Mirshamsi. A. (2014). Impact of different culture media on hairy roots growth of Valeriana officinalis L. Acta agriculturae Slovenica, 103: 299-305. DOI: 10.14720/aas.2014.103.2.14

Pakdin. A., \& Farsi. M. (2013). Effect of different Agrobacterium rhizogenes strains on hairy root induction in Valeriana officinalis L. Continental Journal of Biological Sciences, 6: 9-15.

Porter, R. R. (1991). Host range and implication of plant infection by Agrobacterium rhizogenes. Crit Rev Plant Sci, 10: 387-421. DOI: $10.1080 / 07352689109382318$

Puddephat. I. J., Robinson. H. T., Fenning. T. M., Barbara. D. J., Morton. A., Pink. D. A. C. (2001). Recovery of phenotypically normal transgenic plants of Brassica oleracea upon Agrobacterium rhizogenes-mediated co-transformation and 
selection of transformed hairy roots by GUS assay. Molecular Breeding, 7: 229-242. DOI: 10.1023/A:1011338322000

Resmi. N. R., Anand. M. P., Ramamurthy. S. (2005). TDNA insertional mutagenesis in Arabidopsis: a tool for functional genomics. Electronic Journal of Biotechnology, 8: 82-106.

Sarma. D., Arun. K., Baruah. A. (1997). Transforming ability of two Agrobacterium rhizogenes strains in Rauvolfia serpentina L. leaves. Indian Journal of Plant Physiology, 2: 166-168.

Sharafi. A., Hashemi. S. H., Mousavi. A., Azadi. P., Razavi. K., Ntui. V. O. (2013). A reliable and efficient protocol for inducing hairy roots in Papaver bracteatum. Plant Cell Tissue Organ Cult, 113: 1-9. DOI: 10.1007/s11240-012-0246-2

Sharafi. A., Sohi. H. H., Azadi. P., Sharafi. A. A. (2014). Hairy root induction and plant regeneration of medicinal plant Dracocephalum kotschyi. Physiology and Molecular Biology of Plants, 20: 257-262. DOI: 10.1007/s12298-0130217-z

Sivakumar. G., Yu. K.W., Hahn. E.J., Paek. K.Y. (2005) Optimization of organic nutrients for ginseng hairy roots production in large-scale bioreactors. Current Science, 89: 641-649.

Srinivasan. M., Kumar. K., Kumutha. K., Marimuthu. P. (2014). Influence of acetosyringone concentration on induction of carrot hairy root by Agrobacterium rhizogenes. African Journal of Microbiology
Research, 8: 2486-2491. DOI: 10.5897/AJMR2014.6623

Tamakawa. T., Sekiguchi. S., Kodama. T., Smith. S., Yeoman. M. M. (1998). Transformation of Chilli Pepper (Capsicum frutescens) With a Phenylalanine Amnlonia-Lyase Gene.Plant Biotechnolog, 15: 189-193. DOI: $10.5511 /$ plantbiotechnology.15.189

Tepfer, D. (1984). Transformation of several species of highplants by Agrobacterium rhizogenes: Sexual transmission of the transformed genotype and phenotype. Cell, 37: 959- 967. DOI: 10.1016/00928674(84)90430-6

Tomilov. A., Tomilova. N., Yoder. J. I. (2007). Agrobacterium tumefaciens and Agrobacterium rhizogenes transformed roots of the parasitic-plant Triphysaria versicolor retain parasitic competence. Planta, 225: 1059-1071. DOI: 10.1007/s00425-0060415-9

Wang. J.W., Wu. J.Y. (2013) Effective elicitors and process strategies for enhancement of secondary metabolite production in hairy root cultures. In Biotechnology of Hairy Root Systems (pp. 55-89). Springer Berlin Heidelberg. DOI: 10.1007/10_2013_183

Yamakawa. T., Sekiguchi. S., Kodama. T., Steven. M., Smith. M., Yeoman. M. (1998). Transformation of chilli pepper (Capsicum frutescens) with a phenylalanine ammonia-lyase gene. Plant Biotechnology, 15: 189-193. DOI: 10.5511/plantbiotechnology. 15.189 